Faculty of Philosophy, University of Niš, DOI https://doi.org/10.46630/msae.1.2021.04 Serbia

Original research

\title{
JOURNALISM AND COMMUNICATION STUDENTS' PERCEPTION OF THE USE OF SOCIAL MEDIA NETWORK PLATFORMS IN HIGHER EDUCATION - INSTAGRAM- BASED CASE STUDY
}

\begin{abstract}
The rapid development of technologies and their rapid transformation influenced changes in the world and people's lives and the educational process evolved. Traditional methods of education are enriched with modern technologies, and digital devices become significant elements in modern education. Social network platforms are an important part of life in modern society, they are visited daily by a huge number of people using computers, tablets and smartphones. Their popularity has made them convenient for use in various fields. These platforms have been accepted as student learning support tools, which is why they are increasingly important in the field of higher education. The paper explores the use of social network platforms in higher education, with a focus on social networking services provided by Instagram. In this research, we tried to determine whether the students of journalism and communication used Instagram for educational purposes. Students $(N=100)$ were surveyed through a printed questionnaire at the Faculty of Philosophy. The results show that most students use social networking services for educational purposes. The platform they use for this purpose is Facebook. When it comes to Instagram, most respondents have an Instagram account but do not use it in education.
\end{abstract}

Key words: education, social network platforms, Instagram, Facebook

\section{Introduction}

Rapid technology development and transformation have brought about changes in the world and people's lives. Many aspects of human life have faced innovations, various fields of work and creativity have been improved, the way people spend their spare time, do daily activities and communicate has changed. The use of computers, tablets and smart mobile phones makes lives easier and brings benefits, probably the most important of which being access to and exchange of information, which take place in a second. Education has also succumbed to these changes worldwide

\footnotetext{
${ }^{1}$ Received October 2020 / Accepted December 2020

${ }^{2}$ This paper is part of a master thesis "Specific Instagram capacities in the visual field of formal education", Faculty of Philosophy in Niš (8.10.2019)

3 e-mail: trajkovicjovana09@gmail.com
} 
so that the education informatization has been recognized as an activity of general interest (Nedeljković, 2005: 43). Traditional methods of education are being enriched with modern technologies and digital devices and media have become its significant components. Television sets and video players have long been an integral part of a classroom while computers and projectors have been used by educational institutions at all levels. The use of the Internet is commonplace in primary, secondary and higher education.

An inevitable part of modern life is also related to social network platforms which are visited by a large number of people on a daily basis using computers, tablets and smartphones. Their popularity has made them suitable for use in a variety of fields, in addition to well-known communication and sharing photographs and videos with other people. Additionally, they are gradually included in the educational processes and thus "are a challenge in the higher education teaching process as they are close to students and are an indispensable part of their free time. They can introduce changes in the teaching model, transforming learning into smart nodes within a dynamic and interdependent learning network" (Tomaš, 2014: 45). The role of social network services in higher education is becoming increasingly important as these platforms are gradually adopted to facilitate the learning process and to support students in mastering the material (Stathopoulou, Siamagka \& Christodoulides, 2019: 1, 2). As these social networking services are gaining in importance in the educational process, in this paper we will try to view the role of social network platforms in education, examine their ability to facilitate learning processes and improve communication between teachers and students.

\section{Theoretical Framework}

\subsection{The Use of Social Network Platforms in Higher Education}

The use of social network platforms in higher education has been dealt with by many authors (Neier \& Zayer, 2015; Manca \& Ranieri, 2016; Sobaih, Moustafa, Ghandforoush \& Khan, 2016; Sharma, Joshi, Sharma, 2016; Roblyer, McDaniel, Webb, Herman \& Witty, 2010) and most recognize the potential of social network platforms when it comes to higher education. One of the main reasons these authors consider social network platforms suitable for approaching students is that the younger generations are active on these platforms on a daily basis. Communication through social network platforms has become one of the most important means of communication among people, which is why today it is easy to "virtually" reach students using social network platforms (Zaidieh, 2012: 18). Tomaš also addressed this point, emphasizing that social network platforms are an increasingly important space for communication, cooperation and exchange of ideas in the everyday lives of $21^{\text {st }}$-century generations, which is why it is desirable to guide the education of these generations in a direction that will meet their needs and motivate them to actively participate in the teaching process. He points out that social network platforms are technologically free online services offering communication and cooperation. 
Numerous tools developed within them enable interconnection (Tomaš, 2014: 46). These tools are powerful drivers of change in teaching and learning practices in terms of openness, interactivity and sociability (Manca \& Ranieri, 2016: 216).

As these communication technologies have been accepted by students, they have the potential to improve communication in the field of education and "cooperation with the faculty" (Roblyer et al., 2010: 134). When it comes to students' perceptions of social network platforms as an education tool, Neier and Zayer conclude that students perceive the potential in using these services as a learning tool. Their motive for using social network platforms is reflected in looking for interactivity (Neier \& Zayer, 2015: 3). On the other hand, the potential of using social network platforms for academic purposes is recognized by professors as well, but their actual use for teaching and learning is at a minimal level (Sobaih et al., 2016: 303).

The fact that students recognize the potential of using social network platforms for academic purposes is not unexpected, considering that these platforms have become present in their lives on a daily basis, as a natural form of their communication with peers. It is also important to note that the potential of using social network platforms for academic purposes has been noticed by professors as well, regardless of the generation and degree of use of these services in private life. Even though the results of research by these authors have shown the potentials and advantages when it comes to the use of social network platforms in education, there is a group of authors who concluded that these platforms are marginalized in academic life.

In their research, Manca and Ranieri have shown that the use of social network platforms is still quite limited and that academics are not open to integrate these tools into their practice. They cite several reasons such as cultural resistance, pedagogical issues, or institutional constraints (Manca \& Ranieri, 2016: 216). As a barrier to the introduction of social networking sites in higher education, universities, especially public ones, when it comes to developing countries, often suffer from poor infrastructure and lack of communication technologies and formal electronic methods to connect with their students (Sobaih et al., 2016: 296). Some studies conclude that students tend to use Facebook much more than faculty members and are more open to using Facebook and similar technologies for learning purposes, while faculty members are more inclined to "traditional" technologies, such as e-mail (Roblyer et al., 2010: 134).

Certain authors, such as Stathopoulou et al., point to the positive attitude of both students and teachers when it comes to the use of social network services in education. In their research, they conclude that, according to educators, the use of social media improves students' experience, satisfaction, learning and engagement, while students emphasize the importance of acquiring skills for their future careers such as collaboration, organization and communication (Stathopoulou et al., 2019: 9).

\subsection{Instagram as a Social Network Service and its Use in Education}

Similar to other social network services, Instagram offers communication through the exchange of text and voice messages, posting and exchanging of photos 
and videos, as well as the option to publicly demonstrate that we like another user's post.

Instagram is in a period of growth and change. Two years after it was launched, in April 2012, it was bought by Facebook (Salomon, 2013: 408). Instagram is one of the most popular social network platforms in the world, the number of its users is constantly growing and it currently has more than a billion active users (Statista ${ }^{4}$ ). Also, when it comes to Instagram, it is important to note that it is one of the most influential services for advertising and sales. Since its inception, it has been constantly progressing, with many innovations upgrading it over the years. In 2013, Instagram introduced the Instagram Direct DM option, which is a new way to exchange photos and messages with friends (Instagram press). Inbox icon is access to Instagram Direct, which allows one Instagram user to send messages directly to another user, individually or in groups (Anderson; 2016: 8). In 2016, Instagram extended the limit to the duration of posted videos from 30 to 60 seconds and in the same year another option was introduced: Instagram Story, which allows sharing photos or videos that do not stay on the profile, but disappear 24 hours after posting. Instagram introduced two more significant changes: in 2017 it enabled sharing 10 photos or videos within one post and in 2018 it introduced IGTV - Instagram Television. IGTV allows sharing video content lasting up to an hour and IGTV channels enable users to create contents (Instagram press). These significant changes, as well as many others, have influenced the growth of Instagram's popularity and the expansion of the possibility of being used in various fields.

Instagram is a type of social media networking service created primarily for use via a mobile phone and was originally intended for iPhone users only (Bilton, 2010). Smartphones have been incredibly widespread worldwide, with almost $65 \%$ of adults having access to a smartphone (Colbert et al., 2018: 519). The fact that Instagram is intended for smartphones has partly encouraged its rapid adoption. For this reason, it is increasingly accessible to all generations but is probably the most attractive to the younger ones. Compared to other social network services, Instagram reaches a younger, more diverse audience (Salomon, 2013: 408). This fact is also supported by the results of research into the use and preferences of students when it comes to social network platforms. Some results point to the popularity of Instagram among students, especially female students. After Instagram, the largest number of respondents showed interest in Facebook, with Twitter coming third. Students considered Instagram to be a more reliable social networking site compared to the other two mentioned platforms, although Instagram is owned by Facebook (ShaneSimpson, Manago, Gaggi, Gillespie-Lynch 2018: 281, 283).

When it comes to the use of Instagram in education, the fact that young people are familiar with this social network site can be seen as an advantage, since using it they avoid the trouble and discomfort that could arise when implementing unknown tools in learning activities (McBride, 2009 according to Al-Ali, 2014: 3). Blair and Serafini believe that Instagram is a medium that allows students to connect and

\footnotetext{
${ }^{4} \mathrm{https}: / /$ www.statista.com/statistics/272014/global-social-network platforms-ranked-by-number-of-users/
} 
engage in course concepts and that the way it can be integrated into course content depends on the instructor's imagination. They give a specific example of the use of Instagram in education: at the request of the educator, students could make an Instagram video in which they give an overview of the book being processed, with two key points (Blair \& Serafini, 2014). In that sense, Instagram is presented as a tool that students are familiar with and would not resist and that, on the other hand, offers opportunities for a creative and interactive way of testing knowledge. These authors, however, do not point out special characteristics that would make this social network service more suitable for use in the educational process than other platforms and tools. In any case, there are different Instagram profiles dedicated to teaching in different fields and below we will show how it is used as an aid in learning a foreign language, in the field of medical science, architecture, etc.

\subsubsection{Instagram and Language Learning}

Social network platforms are popular among students, which is why they can be used as a tool in language learning. Instagram is an extremely suitable social networking service for these purposes, as students can post photos or videos their followers can comment on, while educators have the opportunity to make teaching creative (Handayani, 2015: 320).

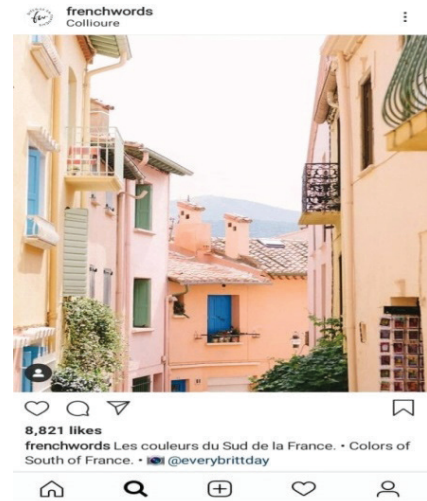

Figure 1 frenchwords

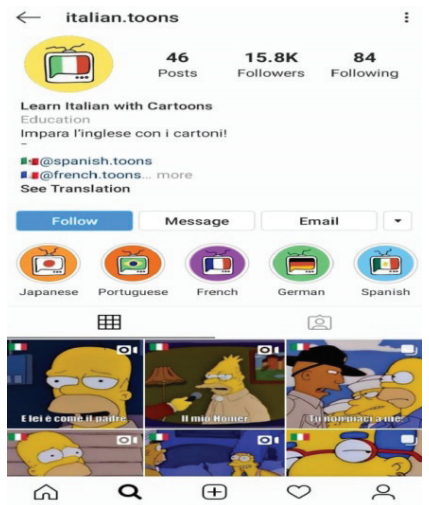

Figure 2 italian toons

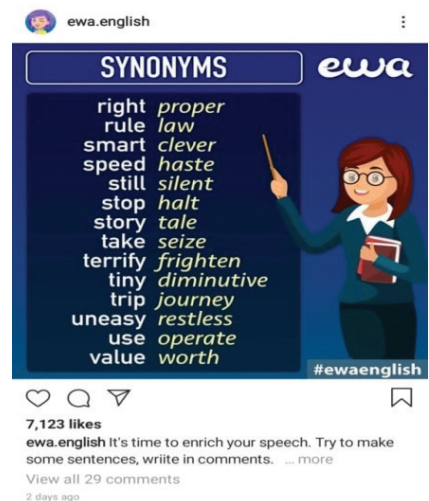

Figure 3 ewa. english

Many authors see the potential of Instagram when it comes to language learning (AlAli, 2014; Blair \& Serafini, 2014; Handayani, 2015). There are a large number of accounts dedicated to this and their approaches to learning are different. A number of accounts focus on vocabulary development, others focus on language grammar, while some focus on pronunciation, but regardless of their content, they can definitely contribute to language learning. Observing Instagram accounts dedicated to learning foreign languages, one notices the freedom and creativity this social networking service offers to educators.

For instance, an extremely popular account called @frenchwords is dedicated to learning French. This profile is followed by 677 thousand followers. The content 
of this account is a combination of French landscapes photos and minimalist photos of pale backgrounds containing a written word or sentence. Photos of French landscapes and architecture are always accompanied by a description in French and its translation into English (Figure 1), while other photos are a French word or a sentence translated into English. The @italian.toons account is intended for teaching Italian. This account posts audio videos of dialogues from cartoons, first in the original in English and then synchronized in Italian (Figure 2). Another example of using this service for language learning purposes is the @ewa.english account, which is extremely popular and is followed by over a million users. This account, dedicated to the English language, explains words and concepts in English, as well as English grammar, through a multitude of photos. An example of such a photo is shown in Figure 3.

These examples suggest that Instagram can be a significant tool in language learning. Students are present on this platform on a daily basis and the content the instructor would post can serve as a reminder of what was covered in class, or as new, brief information. This application can help students develop an "academic vocabulary" (Blair \& Serafini, 2014: 3). Al-Ali also talks about the potential of Instagram in language learning, pointing out that Instagram offers a lot of visual data that can help in mastering a language and the fact that it offers visual elements helps people with the visual learning style. Also, using Instagram in classrooms can help create a community of students, as the tool itself gives students space to communicate and socialize with each other outside the classroom. Interaction on Instagram is mainly done through the functions of liking and commenting (Al-Ali, 2014: 3).

\subsubsection{Instagram and Medical Science}

As is the case with other social network platforms, Instagram is used predominantly for recreational purposes. Despite that, there is a growing number of Instagram accounts related to medical education. Authors who research this field point out that Instagram is used in professional development, but can also serve as an educational tool. The use of this platform in medical education lags behind Facebook and Twitter, as educators perhaps do not recognize its potential role (Shafer, Johnson, Thomas, Johnson \& Fishman, 2018). This is not unexpected since the use of social network platforms in medical education is a new field of learning that requires further research (Cheston, Flickinger \& Chisolm, 2013).

The focus on photography and the visual element Instagram offers fits well with anatomy education as anatomy relies on visual aids that help comprehension and learning. Instagram has offered a number of benefits when it comes to studying anatomy. Research conducted by Douglas et al., which examined active Instagram accounts focused on anatomy education, revealed various successful teaching styles. This includes posting clinical pictures, descriptive videos, multiple-choice questions and cartoons. The benefits of using Instagram for educational purposes are ease of use, hashtags and its efficiency in conveying visual illustrations. These authors give as an example the @seattlesciencefoundation account that posts videos of human 
dissection and surgery, encouraging anatomical interpretation (Douglas et al., 2019: 1,2). An example of the photographs posted by this account is given in Figure 4.

Yakar et al. researched how Instagram is used in neurosurgery and explained how Instagram profiles can have an educational function. They concluded that Instagram can serve as educational support to those educated in the field of neurosurgery. Instagram accounts of renowned journals (e.g., Journal of Neurosurgery), institutional accounts (e.g., Yale Neurosurgery) and personal accounts can serve as an education platform. These accounts guide users through neurosurgical cases, "questioning" users with questions such as "What is the diagnosis?" or "What approach would you use for this injury?" Photos on the Journal of Neurosurgery Instagram profile are unique cases, educational illustrations and disease summaries. Illustrations facilitate learning of complex anatomical structures using photos or videos. Although the information obtained through social network platforms is not always reliable, as this group of authors concluded, Instagram accounts like those given above can expand medical knowledge to those who spend part of their time on Instagram (Yakar, Jacobs \& Agarwal, 2019). Doubt in the reliability of information with an unclear source is also reported by other authors (Douglas et al., 2019: 11).

As the visual side of Instagram is emphasized, it is especially suitable for plastic surgery, a visual surgical specialty. Despite the growing influence of this platform, very few academic publications mention Instagram and even fewer of them evaluate its application in modern plastic surgery (Dorfman, Vaca, Mahmood, Fine \& Schierle, 2017: 332). There is a large number of Instagram accounts posting photos related to plastic surgery. There are numerous accounts of professionals who promote their work through social network platforms by posting "before and after" photos, short videos showing the basic steps of a procedure, the patient's recovery phase, the patient's look at the beginning and end of the procedure and the like. On the other hand, there are also accounts dedicated to education. The potential of such educational accounts is noticeable, but it has not been investigated whether and to what extent it has been utilized. Economides et al. believe it is unlikely that academic surgeons will include social network platforms in their practice (Economides, Fan \& Pittman, 2018: 801). The presentation of plastic surgery on Instagram is also examined by Dorfman et al. They examine the use of hashtags related to plastic surgery in education and marketing and come to the conclusion, which can be related to the subject of this research, that most Instagram posts related to plastic surgery were published for self-promotion purposes (67\%), beating posts for educational purposes (about 33\%) (Dorfman et al., 2017: 332 - 334).

\subsubsection{Instagram and Other Fields}

In addition to language learning and medical science, Instagram is a social networking service noticeably used in other fields of education as well. It is also attractive to students of architecture because of the emphasized visual element. Architects and students often post photos of their work, from drawings and models to large-scale buildings. From the perspective of an accredited school of architecture, 
Adams and Mohamed claim that Instagram has great potential when it comes to connecting with other schools, as well as that Instagram can expose student work to a global audience and reach donors in new ways (Adams \& Mohamed, 2016: 407). The use of Instagram has shown positive results in teaching sports biomechanics, according to a study by Navandar et al. They believe that Instagram could turn into a powerful resource in the undergraduate study programs of sports science as it can help in learning sports movement patterns. Its popularity among young people and its visual characteristics make it a perfect addition to existing teaching methods (Navandar, López \& Alejo, 2019: 335). Salomon examined the use of Instagram by the university library. She described how the library had successfully used this application to connect with students. She pointed out that Instagram had become a fun learning tool for their students and described the learning process as follows: the educator posted a photo on his Instagram profile with a question in the description, then followers gave assumptions in the answers and the educator wrote the correct answer at the end of the conversation (Salmon, 2013: 410).

Although the scope of research into using Instagram for social media networking services in education is small, the largest number of papers collected for the purpose of writing this paper is from the field of language learning and medical education. In addition to these fields, others have been identified that can use Instagram as an aid tool in providing education. In this research, Instagram has been presented as a social network service that is well known to and easily used by the young generations and students. If we take into account these facts and the knowledge that these generations spend a lot of free time using Instagram, we conclude it is tempting to use for educational purposes. When it comes to knowledge transfer, the visual side of this social network platform is increasingly emphasized. Also, the authors cite the possibility of interaction and expression of creativity as a significant feature of Instagram, which is very desirable when it comes to education.

\section{Methodological Framework}

The subject of this research is the potential of using social network platforms in higher education, with a focus on Instagram. The main goal is to examine the degree of use of these platforms for educational purposes by students.

For the purposes of this paper, research was conducted to examine the opinions and attitudes of the students of the Faculty of Philosophy in Niš concerning the use of social network platforms in higher education. A special focus was on examining their views when it comes to using Instagram as a social networking service. The results should show whether students used social network platforms in education, and if so, which platforms they used. Also, the results should show whether students perceived the potential of Instagram in education and whether they used it for those purposes.

This research used the survey research method. The survey consisted of 13 questions, of which 6 were open-ended questions and 7 were closed-ended questions 
with offered answers. The survey was conducted among students of undergraduate studies at Faculty of Philosophy, University of Niš, from the Department of Communication and Journalism. Students $(\mathrm{N}=100)$ were surveyed through a printed questionnaire at the Faculty of Philosophy.

\section{Research Results}

The following chapters will be dedicated to presenting the results obtained through the survey. The results of the survey which examines the attitudes of students about the use of social media platforms in higher education will be shown in a quantitative and qualitative presentation.

\subsection{Quantitative Presenting of Survey Results}

To the first question related to the use of social network platforms, $98 \%$ of students answered that they have an account on a platform, while $2 \%$ answered in the negative. Most students use Facebook (90\%), then Instagram (85\%) and Twitter (22\%). In addition to these, students listed some other social network platforms: LinkedIn (10\%), Snapchat (6\%), YouTube (5\%), Pinterest, Tumblr, and Vkontakte (4\% each). Almost all students stated that they use the platforms on a daily basis (90\%), a small number of them reported using them on a weekly basis (6\%), monthly basis $(3 \%)$ and rarely (1\%), while none of the students said they did not use these platforms at all.

Regarding the question "How do you most often access social network platforms?", the students could mark one of the three options. The largest number of students reported they accessed social network platforms via mobile phone (96\%) and a small number indicated they accessed them via computers (3\%) and tablets (1\%). The students were asked "Which social network platforms do you use most often?", to which they most often gave more answers, that is, they listed several platforms they typically use. In $79 \%$ of cases, the students reported Instagram, Facebook in $48 \%$ and Twitter in 25\%. Students also reported LinkedIn (5\%) as the social network service they used most often.

The survey also examined students' motivation to use social network platforms by offering certain answers. The answers were as follows: for communication (90\%), for fun $(78 \%)$, to connect with colleagues (20\%), for education (25\%), for sharing professional success (15\%), for meeting new people (13\%). The respondents were asked a question regarding their opinion on whether social network platforms can be used in higher education. The largest number of respondents answered in the affirmative (74\%), a certain number of them answered in the negative (11\%) or did not have an opinion on this issue (15\%). When asked if they use social network platforms in higher education, $79 \%$ of students gave an affirmative answer, while $21 \%$ answered in the negative. The survey asked the question "How can social network platforms be used in higher education?”. Among the students' answers, the most prominent 
was related to Facebook as a social network platform. Particularly emphasized were Facebook groups, which students reported as a means of communicating with colleagues and professors, as well as accessing information and materials needed for exams. A large number of students mentioned the Facebook groups of departments they form to communicate with each other and exchange information and materials related to their studies.

The question "Which social network platform do you think is the most suitable for use in education?" was answered by 87 students, of whom $80 \%$ reported Facebook as the most suitable social network service for use in higher education, $12 \%$ answered Instagram and the lowest percentage of students (8\%) stated Twitter. The respondents were asked whether they had used social network platforms in their education so far and the answers to this question were similar to the answers to the question of how social network platforms can be used in higher education. The students mostly answered in the affirmative and talked about the use of Facebook for educational purposes.

The students were asked questions related to the use of Instagram - they were asked about the purposes they used this social network platform for. The answers showed that students most often used this service for entertainment, photo posting and communication purposes. When it comes to the use of Instagram in higher education, a slightly higher number of students thought that it could not be used for those purposes (47\%) compared to those who think that it could (31\%). A number of students (22\%) did not have an opinion on this issue. Also, when asked if they used Instagram in higher education, students answered as follows: $78 \%$ did not use Instagram for educational purposes, while $22 \%$ did.

\subsection{Discussion}

The survey first revealed that all students used social media platforms. Although a very low percentage of students stated that they did not have an account on any of the platforms, no student stated that they never used social media networking platforms, based on which we assumed that students who did not have an account on one of these platforms accessed it without an account. The social media platforms that were the most popular among students are Facebook and Instagram. These social media platforms were constantly present in the lives of the surveyed students, as most of them used these platforms on a daily basis. Although the percentage of students who had a Facebook account was slightly higher than the percentage of those who had an Instagram account, the majority emphasized that they used Instagram more often compared to Facebook and other social media platforms. The respondents usually accessed social media networking platforms via a mobile phone, and that was the main advantage of Instagram over other platforms - it was adapted primarily for a smartphone. These two facts, that Instagram was the most popular platform among students and that students accessed it every day via the mobile phone they had with them at almost any time, made this platform a channel that makes communication with students accessible. 
Most respondents used social media networking platforms for communication and entertainment purposes, but most also saw the potential of such platforms in education and believed that they could be used for those purposes. Therefore, the fact that most students actually used social media sites for educational purposes was not surprising. The largest number of students indicated that Facebook was the social media platform that was the most suitable for use in higher education. Also, when asked how social media platforms could be used in higher education, students usually gave explanations that included Facebook groups. Finally, when asked how they used these platforms in their education so far, most students gave descriptions of use that referred to Facebook as a channel for communication with colleagues and professors, exchange of information and content related to studies.

As the focus of this research was on Instagram, the students were asked about the purposes they used this social media platform for. Research results showed that this platform was often a source of entertainment, a means of posting photos and communication. However, when it came to using Instagram for educational purposes, most students did not use this platform for these purposes - as many as $78 \%$. The students also expressed an opinion on whether Instagram offered potential when it came to higher education. Although students' opinions were divided, the largest number of students (47\%) ruled out the possibility of using this social networking service for educational purposes. Although almost a third of students (31\%) notice the potential of this platform, most of the surveyed students do not have a positive attitude about using Instagram for educational purposes.

\section{Concluding Remarks}

Social media networking platforms are being gradually incorporated into educational processes. The available literature related to the use of these platforms in education most often mentions the use of Facebook for these purposes. As the focus of this paper was Instagram as a social media platform, we noticed that it was more suitable for certain scientific disciplines, while others did not recognize it as an educational tool. Thus, for example, in the studies of architecture and design, the potential of Instagram was noticed as it was based on a visual element. Medical science could also take advantage of this platform, as illustration and imagery were of great importance in their study. Also, Instagram was useful in language learning as it offered photos and sounds. However, journalism and communication students did not find a way to incorporate Instagram as a tool that could facilitate their professional advancement.

The results of this research showed that social media network platforms were present in students' lives on a daily basis. Almost all students were active on one of the social media platforms every day, and they usually accessed these services via mobile phones. Most students had experience with these platforms in higher education, so they had a positive opinion about their use in this field and were open to this mode of working. The 
platform with which they had the most experience and which they talked about the most in this context was Facebook. Through Facebook groups, they exchanged information and materials for work and learning. However, when it came to Instagram - the situation was different. Unlike Facebook, which was rated as the most suitable social media network platform for educational purposes, students did not see that Instagram had the potential when it came to their studies, education, and learning. Although most of the surveyed students had a Facebook account, they most often used Instagram. They were online almost constantly, and since they most often used Instagram, they could be reached at any time through this platform. Instagram offered a new channel through which students could be reached unobtrusively, and as they were well acquainted with the way Instagram worked, the process of introducing students to a new platform that would serve education was avoided. Also, students were usually present in private on this platform, which would not be the case with other platforms dedicated for use in education. At the moment, in addition to all of the options this platform offered, the potential of using Instagram for educational purposes was reflected in its noticeable popularity among students. In that sense, Instagram could be used as a learning tool.

\section{References}

Adams, A., Mohamed, B. E. (2016). „\#McGillarchitecture: design education in the age of Instagram". Ed. P. Weber. International Peer-reviewed Conference on 'Research Based Education'. (pp. 407-415). London: The Bartlett School of Architecture, UCL. URL: https://www.researchgate.net/publication/304038983_McGillarchitecture_design_ education_in_the_age_of_instagram (Accessed March 14, 2019).

Al-Ali, S. (2014). "Embracing the Selfie Craze: Exploring the Possible Use of Instagram as a Language mLearning Tool”. Iss.s and Trends in Educational Technology. Vol 2, Iss. 2, pp. 1-16. DOI: https://doi.org/10.2458/azu_itet_v2i2_ai-ali

Anderson, K. E. (2016). "Getting acquainted with social network platforms and apps: Instagram's instant appeal”. Library Hi Tech News. Vol 33, Iss. 3. pp, 11-15. DOI: https://doi.org/10.1108/LHTN-03-2016-0011

Bilton, N. (21 December 2010). “Instagram Quickly Passes 1 Million Users”. The New York Times. Available on: https://bits.blogs.nytimes.com/2010/12/21/instagram-quicklypasses-1-million-users/ (Accessed December 18, 2020).

Blair, R., Serafini, T. M. (2014). "Integration of education: Using social media network platforms to engage students". Systemics, Cybernetics, and Informatics. Vol 6, No 12, pp. 28-31. URL: http://www.iiisci.org/journal/CV\$/sci/pdfs/HA312LG14.pdf (Accessed March 14, 2019).

Cheston, C. C., Flickinger, T. E., \& Chisolm, M. S. (2013). "Social media use in medical education: a systematic review”. Academic Medicine, Vol 88, Iss. 6, pp. 893-901. DOI: https://doi.org/10.1097/ACM.0b013e31828ffc23

Colbert, G. B., Topf, J., Jhaveri, K. D., Oates, T., Rheault, M. N., Shah, S., Hiremath, S., Sparks, M. A. (2018). "The social media revolution in nephrology education". Kidney international reports, Vol 3, Iss. 3, pp. 519-529. DOI: https://doi.org/10.1016/j.ekir.2018.02.003 
Dorfman, R. G., Vaca, E. E., Mahmood, E., Fine, N. A., Schierle, C. F. (2017). "Plastic surgery-related hashtag utilization on Instagram: Implications for education and marketing”. Aesthetic surgery journal, Vol 38, Iss. 3, pp. 332-338. DOI: https://doi. org/10.1093/asj/sjx120

Douglas, N. K. M., Scholz, M., Myers, M. A., Rae, S. M., Elmansouri, A., Hall, S., Border, S. (2019). "Reviewing the Role of Instagram in Education: Can a Photo Sharing Application Deliver Benefits to Medical and Dental Anatomy Education?". Medical Science Education 29, pp. 1117-1128. DOI: https://doi.org/10.1007/s40670-01900767-5

Economides, J. M., Fan, K. L., Pittman, T. A. (2018). “An analysis of plastic surgeons' social media use and perceptions". Aesthetic surgery journal. Vol 39, No 7, pp. 794-802. DOI: https://doi.org/10.1093/asj/sjy209

Handayani, F. (2015). "Instagram as a teaching tool? Really?". Proceedings of ISELT FBS Universitas Negeri Padang. Vol 4, No 1, pp. 320-327. URL: https://www.researchgate. net/publication/335241024_INSTAGRAM_AS_A_TEACHING_TOOL_REALLY (Accessed March 21, 2019).

Manca, S., Ranieri, M. (2016). "Facebook and the others. Potentials and obstacles of social media for teaching in higher education". Computers \& Education. Vol 95, pp. 216-230. DOI: https://doi.org/10.1016/j.compedu.2016.01.012

Navandar, A., López, F. D., Alejo, L. B. (2019). "Using Instagram in the sports biomechanics classroom”. ISBS Proceedings Archive, Vol 37, Iss. 1, pp. 332-335. URL: https:// commons.nmu.edu/isbs/vol37/iss1/81 (Accessed September 5, 2019).

Nedeljković, M. (2005). "Pretpostavke i implikacije informatizacije obrazovanja." Tehnologija informatika obrazovanje 3, pp. 43-52.

Neier, S., Zayer, L. T. (2015). “Students' perceptions and experiences of social media in higher education". Journal of Marketing Education. Vol 37, No 3, pp. 133-143. DOI: https://doi.org/10.1177/0273475315583748

Roblyer, M. D., McDaniel, M., Webb, M., Herman, J., Witty, J. V. (2010). “Findings on Facebook in higher education: A comparison of college faculty and student uses and perceptions of social networking sites". The Internet and higher education. Vol 13, Iss. 3, pp. 134-140. DOI: https://doi.org/10.1016/j.iheduc.2010.03.002

Salomon, D. "Moving on from Facebook: Using Instagram to connect with undergraduates and engage in teaching and learning." (2013). College \& Research Libraries News. Vol 74, No 8, pp. 408-412. DOI: https://doi.org/10.5860/crln.74.8.8991

Shafer, S., Johnson, M. B., Thomas, R. B., Johnson, P. T., Fishman, E. K. (2018). “Instagram as a Vehicle for Education: What Radiology Educators Need to Know". Academic radiology. Vol 25, Iss. 6, pp. 819-822. DOI: https://doi.org/10.1016/j.acra.2018.03.017

Shane-Simpson, C., Manago, A., Gaggi, N., Gillespie-Lynch, K. (2018). "Why do college students prefer Facebook, Twitter, or Instagram? Site affordances, tensions between privacy and self-expression, and implications for social capital". Computers in Human Behavior. Vol 86, pp. 276-288. DOI: https://doi.org/10.1016/j.chb.2018.04.041

Sharma, S. K., Joshi, A., Sharma, H. (2016). "A multi-analytical approach to predict the Facebook usage in higher education". Computers in Human Behavior. Vol 55, pp. 340353. DOI: https://doi.org/10.1016/j.chb.2015.09.020 
Sobaih, A. E. E., Moustafa, M. A., Ghandforoush, P., Khan, M. (2016). “To use or not to use? Social media in higher education in developing countries". Computers in Human Behavior. Vol 58, pp. 296-305. DOI: https://doi.org/10.1016/j.chb.2016.01.002

Stathopoulou, A., Siamagka, N., Christodoulides, G. (2019). "A Multi-stakeholder View of Social Media as a Supporting Tool in Higher Education: An Educator-Student Perspective." European Management Journal. DOI: https://doi.org/10.1016/j.emj.2019.01.008

Tomaš, S. (2014). "Oblikovanje nastavnih sadržaja na društvenim mrežama u visokoškolskom obrazovanju”. Školski vjesnik. Vol 63, No 3, pp. 309-326. URL: https:// hrcak.srce.hr/136068 (Accessed March 16, 2019).

Yakar, F., Jacobs, R., Agarwal, N. (2020). “The current usage of Instagram in neurosurgery”. Interdisciplinary Neurosurgery. Vol 19, Article 100553. DOI: https://doi.org/10.1016/j. inat.2019.100553

Zaidieh, A. J. Y. (2012). "The use of social networking in education: Challenges and opportunities". World of Computer Science and Information Technology Journal. Vol 2, No 1, pp. 18-21. URL: shorturl.at/wJXZ0 (Accessed March 16, 2019).

\title{
Internet sources:
}

Instagram-press. "Our story”. https://instagram-press.com/our-story/

Statista. "Number of monthly active Instagram users".

https:/www.statista.com/statistics/253577/number-of-monthly-active-instagram-users/

\section{PERCEPCIJA STUDENATA NOVINARSTVA I KOMUNIKOLOGIJE O UPOTREBI INSTAGRAMA U VISOKOM OBRAZOVANjU}

\begin{abstract}
Apstrakt: Brzi razvoj tehnologija i njihova brza transformacija uticali su na promene u svetu $i$ životu ljudi, a promenama je podlegao i proces obrazovanja. Tradicionalne metode obrazovanja oplemenjuju se modernim tehnologijama, a digitalni uređaji postaju značajni činioci savremene edukacije. Nezaobilazni deo života savremenog društva su društvene mreže koje uz upotrebu računara, tableta i telefona svakodnevno posećuje ogroman broj ljudi. Njihova popularnost učinila ih je pogodnim za korišćenje u raznim oblastima. Ove platforme su prihvaćene kao alati podrške studentima pri učenju i zbog toga su sve značajnije u oblasti visokog obrazovanja. U radu se istražuje upotreba društvenih mreža u visokom obrazovanju, sa fokusom na društvenu mrežu Instagram. $U$ istraživanju smo pokušali da utvrdimo da li studenti novinarstva i komunikologije koriste ovu mrežu u svrhe obrazovanja. Rezultati pokazuju da većina studenata koristi društvene mreže u svrhe obrazovanja. Mreža koju u te svrhe koriste je Fejsbuk, a kada je u pitanju Instagram, većina ispitanika ima otvoren profil, ali ga ne koristi u obrazovanju.
\end{abstract}

Ključne reči: obrazovanje, društvene mreže, Instagram, Facebook

\footnotetext{
${ }^{5}$ Ovaj rad deo je master rada „Specifični kapaciteti Instagrama u vizuelnoj oblasti formalnog obrazovanja" odbranjenog na Filozofskom fakultetu u Nišu (8.10.2019).
} 